\title{
Article \\ Industry 4.0: A Technological-Oriented Definition Based on Bibliometric Analysis and Literature Review
}

\author{
Mario Rupp ${ }^{1, *(\mathbb{C})}$, Max Schneckenburger ${ }^{2}\left(\mathbb{D}\right.$, Markus Merkel $^{1}\left(\mathbb{D}\right.$, Rainer Börret $^{2}$ and David K. Harrison ${ }^{3}(\mathbb{D}$ \\ 1 Institute for Virtual Product Development, Aalen University, 73430 Aalen, Germany; \\ Markus.Merkel@hs-aalen.de \\ 2 Centre of Optical Technologies, Aalen University, 73430 Aalen, Germany; \\ Max.Schneckenburger@hs-aalen.de (M.S.); Rainer.Boerret@hs-aalen.de (R.B.) \\ 3 School of Computing, Engineering and Built Environment, Glasgow Caledonian University, \\ Glasgow G4 0BA, UK; D.Harrison@gcu.ac.uk \\ * Correspondence: mario.rupp@hs-aalen.de
}

Citation: Rupp, M.; Schneckenburger, M.; Merkel, M.; Börret, R.; Harrison, D.K Industry 4.0: A Technological-Oriented Definition Based on Bibliometric

Analysis and Literature Review. J. Open Innov. Technol. Mark. Complex. 2021, 7 , 68. https://doi.org/10.3390/ joitmc7010068

Received: 17 December 2020

Accepted: 5 February 2021

Published: 20 February 2021

Publisher's Note: MDPI stays neutral with regard to jurisdictional claims in published maps and institutional affiliations.

Copyright: () 2021 by the authors. Licensee MDPI, Basel, Switzerland. This article is an open access article distributed under the terms and conditions of the Creative Commons Attribution (CC BY) license (https:// creativecommons.org/licenses/by/ $4.0 /)$
Abstract: Industry 4.0 was introduced in 2011 and since then has been perceived in multiple ways such as a vision, a paradigm, a scenario or as a digital revolution in production and service organizations. Even though Industry 4.0 is associated with great improvements for companies, there is still a lack of a uniform definition of the term Industry 4.0, especially when it comes to the transfer of knowledge from theoretical research to the implementation in organizations, which leads to confusion and disaffirmation. The lack of a clear structure and a holistic definition of the research topic Industry 4.0 inhibits the development of new business areas and new research approaches. To target this fundamental gap, a methodology is developed and the 338 most relevant publications are analyzed in the database of ScienceDirect starting from 2015. Based on those publications, the field of Industry 4.0 is structured. A consistent and comprehensive definition for Industry 4.0 is introduced by using a bibliometric analysis. Therefore, existing descriptions are decomposed into word fragments and analyzed. It is shown that this novel approach to find a definition for the term "Industry 4.0" does not yet exist. The aim is to provide a purely objective definition based on a statistical evaluation, without restricting the selection of publications to a specific research or business area. Based on those data, a new and ubiquitous definition of Industry 4.0 is formed, discussed and validated on practical examples.

Keywords: bibliometric analysis; definition; technology; Industrie 4.0; literature review

\section{Introduction}

The production world is reacting to the customers' needs for individualized and innovative products by adopting digital technologies. The existing and established paradigms in the production world such as Lean Production are now faced with the upcoming digitalization process, also known as Industry 4.0. The German research community shaped and introduced the term as the next industrial revolution, preceded by mechanization (1.0), mass production (2.0) and the automation (3.0) industries [1]. At the fair 'Hannover Messe 2011', the term 'Industrie 4.0' (Engl. 'Industry 4.0') was introduced for the first time by Siegfried Dais and Henning Kagermann [2]. Both were founding fathers and driving forces behind the project leading the high-tech strategy of the German government. The aim of the project was to promote the computerization of manufacturing [3]. Although the terms Industry 4.0 and fourth industrial revolution are often used interchangeably, Industry 4.0 is just a subset of the fourth industrial revolution [4].

Driven by developments in communication, data knowledge and storage, the manufacturing sector is trying to adopt technologies to increase individuality, innovation and productivity and to decrease and reduce error rates [5]. On the one hand, a major benefit of Industry 4.0 is the interconnection and decentralization of companies and their technologies 
to support the drive of Open Innovation [6]. Whereas innovation is limited in organizations, the digitization opens up the companies and connects it with suppliers, customers and other decentralized locations $[7,8]$. With an increasing communication of people and customers outside of the company, knowledge is directed faster into the organization, which leads to a growing open innovation dynamic [9]. To adopt the innovation process, studies have shown that technological standardization and formalization are key enablers [10]. On the other hand, open innovation also is able to increase the implementation of technologies and the momentum of Industry 4.0 [9]. According to this perspective, the combination of open innovation and Industrie 4.0 can be understood as a positive interaction. They influence each other in a mutually supportive way.

Previous industrial revolutions were driven by single technology inventions such as the steam engine (1.0), electricity (2.0) and computers (3.0). In contrast, the ongoing fourth industrial revolution is driven by existing technological developments and the ability to process large amounts of data. As a consequence, the integration of the physical space and the cyber physical space is expected [11]. Thereby, authors are arguing that Industry 4.0 is an idea, a vision, a concept or a paradigm. Due to the lack of a clear structure and a holistic definition, the young and fast evolving research topic of Industry 4.0 has become a buzzword for many applications and research fields. Businesses are using this actual trend for introducing long-term strategies in order to show their future-oriented approach. Safe communication systems [12], new business models [13] as well as sensors and actuators for the business architecture [14] are the scope of research. In contrast, Jeske et al. argues that companies are unable to connect with the term and successfully implement the digital structures in their organizations [15]. They conducted an online survey demonstrating that the general public has evolved fast and adjusted to Industry 4.0, whereas companies are struggling to implement its technologies and principles [15]. Even if $90 \%$ of the employees are familiar with Industry 4.0, only 30\% know the practical meaning of this term [15]. Nevertheless, the phrase of Industry 4.0 is not clearly defined yet. One of the main aim of the present work is to find a proper definition. Therefore, the authors waive any detailed description at this point.

Commonly, definitions enable an objective understanding of a phrase and create value beyond its intended purpose of describing something effectively [16]. The absence of a clear definition of Industry 4.0 may result in a loss of confidence in understanding this term and lead to a restriction of its usage. To gain a better understanding, definitions can facilitate a business' discussions, strategic developments and implementations. The aim of this present work is to provide a structured literature review of Industry 4.0 and create a reliable, general and uniform definition of Industry 4.0 based on bibliometric analysis. The phrase evolved starting from the classical engineering and production processes in the manufacturing industry to a widely spread term also used in the construction Industry [17], food sector [18], medicine [19,20], supply chain [21,22], farming [23] and logistics [24,25].

In the following chapter, the procedure and methodology are presented. For this purpose, the descriptions of 'Industry 4.0 ' are collected from numerous publications. These text fragments are then analyzed and evaluated for the frequency of the individual words that occur. The procedure has not yet been used in any known publication. Section 3 gives a structured overview of what the collected publications describe. The term is divided into organizations, technologies and people, which are considered individually. Section 4 then looks at the bibliometric analysis: which single word or keyword was used and with which other words. From these terms, an objective definition is formed in Section 5. The paper is then discussed and the definition validated by using examples. Finally, the summary is presented. The aim of this publication is to create a scientific and objective definition of the term 'Industry 4.0'. This paper is characterized by an objective viewpoint; a clear definition is created by statistically averaging many individual descriptions of the analyzed term. The basis for this is the use of objective algorithms. 


\section{Material and Methods}

\subsection{Planning and Preparation}

To mirror the international research community, both the German and the English phrase have been used for systematic literature research. To determine the time period of the analysis, search queries recorded by Google Trends for the introduced terms were analyzed. Studies have shown that Google search queries and trends are suitable as a scientific analysis tool [26]. In an interdisciplinary way, increased queries could be analyzed via Google trends and, in retrospect, directly linked to innovations and changes in the market $[27,28]$.

As shown in Figure 1, search queries increased significantly in 2015, three years after the introduction of Industry 4.0. Both of the search terms 'Industry $4.0^{\prime}$ ' and 'Industrie 4.0' started to increase. The highest attention was in January 2020 for the English search term. Therefore, the time frame was set to publications from January 2015 up to July 2020.

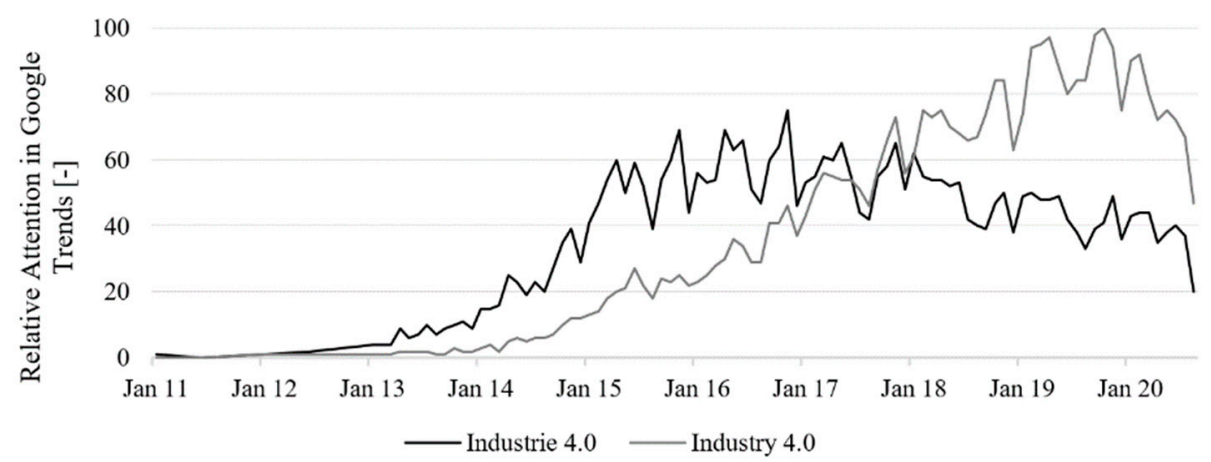

Figure 1. Relative search attention of 'Industrie 4.0' and 'Industry 4.0' in Google Trends (January 2011 to July 2020).

To develop a framework for the literature research, this publication is focused on objectivity and uniformity. The database of Elsevier is amongst the most qualified representatives for technological-orientated research publications. It covers a huge amount of interdisciplinary and international journals and papers in the field of engineering but is not limited to other disciplines. Since the aim of the study was to find definitions, only full-text papers listed in the platform of ScienceDirect were analyzed (Figure 2) [29,30]. Other databases such Web of Science or Google Scholar were not considered for the present work, nevertheless they might lead to other specific results in reviewed literature and the created definition.

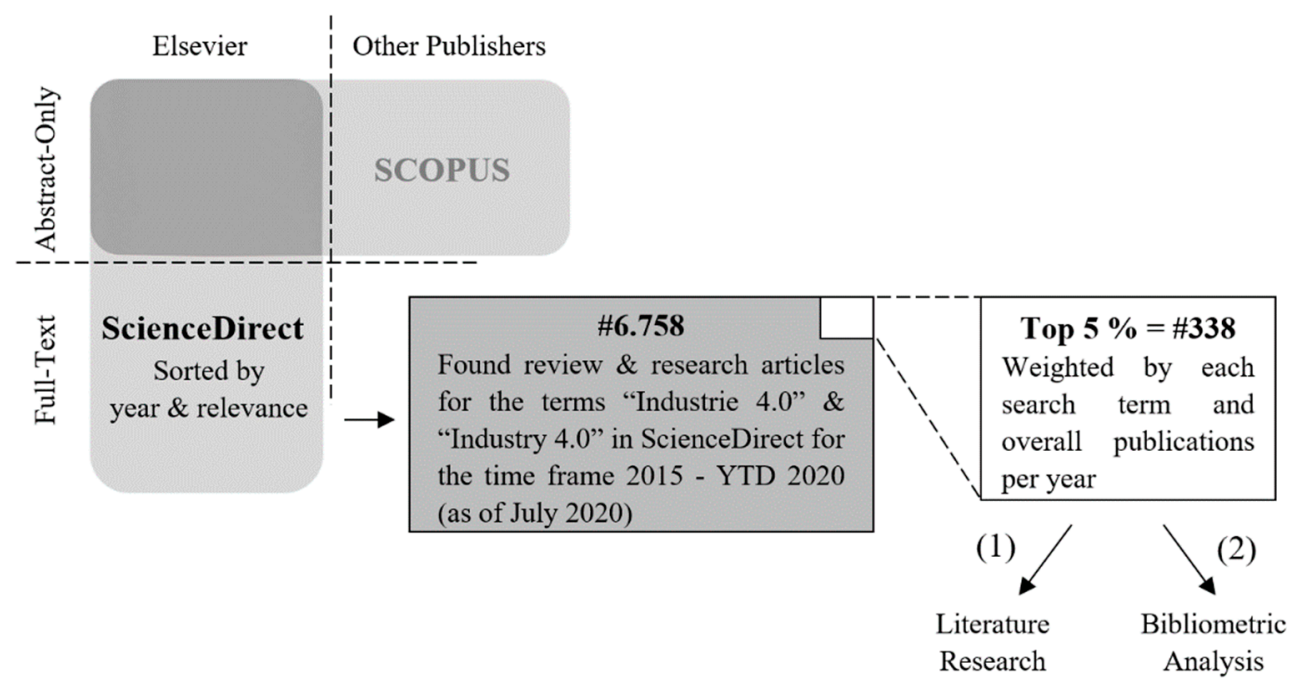

Figure 2. Developed methodology and workflow for literature research. 
Within the found publications in ScienceDirect, several specifications have been made. Only the top 5\% publications were considered based on the yearly amount of publications. As reference, those publications were prioritized by using the relevance function of the database itself. By default, search engine relevance is an intricate calculation, which shows how well text in the documents returned as search results reflect the terms and criteria executed in a search query. The search engine ScienceDirect uses a relevance model based on concepts from the science of information retrieval [30]. Each publication returned as a result by a query is given a score composed of a variety of different factors, like the amount and position in the publication, proximity and completeness and significance of the search term [31].

As shown in Figure 2, 6.758 relevant publications were found overall, which leads to a top $5 \%$ of 338 publications for the time frame. These publications are analyzed for the literature research (1) and also were used as basis for forming a definition with a bibliometric analysis tool (2). The $5 \%$ of publications represents the sample size with a margin of error of $5 \%$ and a confidence level of $90 \%$ [32]. The confidence level of the sample considered that the word 'Industry $4.0^{\prime}$ ' is a hypothetical topic right now and is used in many publications without a definition or without going into more detail about the term. A value below the standard deviation can be chosen if such assumptions can be made [33]. The selected sample value must therefore be at least 262 out of 6.758 definitions. A total of 338 publications were analyzed in this study, a value that is above the targeted sample value.

\subsection{Data Collection}

Based on the introduced methodology in Figure 2, Figure 3 shows the detailed distribution of the publications per year and per search term. Overall, 99 publications have been found in 2015 (35 for Industrie 4.0, 64 for Industry 4.0), whereas this number increased to 2.436 publications found in 2019 (357 for Industrie 4.0, 2079 for Industry 4.0). By taking a closer look on the search terms, the English term was used in about $84 \%$ of all publications. For the top 5\% within the specifications, 338 out of the 6.758 publications have been weighted to each year.

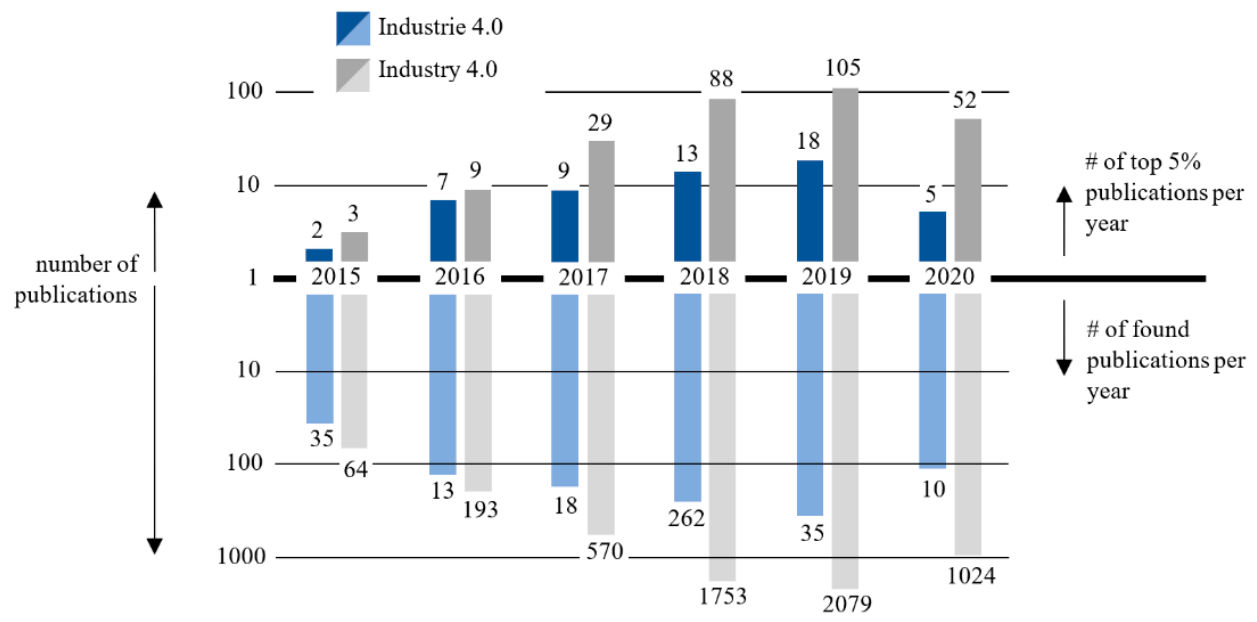

Figure 3. Relevant publications within the specifications for literature research and bibliometric analysis.

For the year 2018, as an example, 262 publications with the keyword 'Industrie 4.0' were found. The top $5 \%$ of these publications were relevant for the literature research and the building of the definition, which involved 13 publications.

Summarizing, the overall number of publications and the contribution of the English and German terms were transferred to the publications for each year and each term. This methodology guarantees a view only on the most relevant and best ranked publications of Industry 4.0 for the literature research and the forming of a definition. 
Due to rounding errors, a total of 340 publications were considered for further proceeding.

\section{Structuring Industry 4.0}

The following section shows the most important findings and results of the research in the defined period (2015-July 2020). The literature review includes an overview of the nomenclatures and focuses on the aspects of organization, people and technologies.

Following the introduction in Germany, many nomenclatures have been developed in other countries. Afterwards, the English phrase 'Industry 4.0' became the main international term. In the USA, several initiatives have been founded, including the 'Advanced Manufacturing Partnership', the 'Advanced Manufacturing Partnership (AMP)' and the 'Smart Manufacturing' initiative [34-38]. In the European region, for example, the Czech government allocated support for relevant projects following their own program 'Initiative Industry 4.0' [39] and the UK set up their 'Future of Manufacturing' program [37]. In 2015, China published its 10-year-plan to transform its manufacturing industry called 'Made in China 2025' [35,40] and Japan introduced their 'Industrial Value-Chain Initiative' [35].

Among the reviewed literature, different approaches exist to structure Industry 4.0. Kamble et al. for example structured their review regarding the maturity of industry [41]. Other authors used the technological perspective like Zhong et al. [35]. Also, Culot et al. followed this approach [42]. Bigliardi et al. structured their bibliometric review by using the application areas [43]. Within a holistic approach, Beier et al. structured Industry 4.0 into four categories: human (1), technology (2), organization (3) and features (4) [44].

Despite the great research effort, currently there is no unanimously agreed definition $[40,45,46]$, characterization [47], concept or roadmap [44,48] available. In the beginning, Industry 4.0 often was sketched as a vision of smart factories or as a scenario for a forth industrial revolution [49-51]. As there was no concrete description of the term, a variety of paraphrases were used such as 'Trend' [51,52], 'Framework' [53] or 'Phenomenon' [54,55]. Other authors used terms like 'high-sky-vision' or 'visionary concept' to underline the theoretical background and the lack of reference to the real production environment $[56,57]$. A frequently used term is 'concept' or 'umbrella' of Industry 4.0 [56-61]. Descriptions vary in their focus, their scope and their information density, which slows down the academic progress [47]. Due to the lack of a standard definition, research fields started adopting multiple understandings of Industry 4.0. This makes it even more complex to focus on a holistic development and to converge on the scope and synthesize the objectives [47,62]. A missing definition also led to a lack of acceptance in the community, meaning Industry 4.0 started to be described as a 'flashy catchphrase' [43].

Authors seek definitions to drive implementation of changes in an industry [63]. Without clear structured concepts based on a definition, adoption and acceptance in industry is stagnating [64]. Moreover, authors try to target its aim in order to get a better understanding of the topic. Therefore, focus is on the realization of continuous improvements [65] and digital manufacturing [66,67]. On the other side, authors argue that it might be too early to define Industry 4.0 in a proper way. Given the time available, implementation might take decades [57].

Besides the evolution of the definition on the one hand, Industry 4.0 has been consistently referred to as a 'paradigm' since its introduction. A paradigm at this point can be understood as a fundamental way of thinking which implies the need for a holistic view of Industry 4.0 to classify the topic. Therefore, this paper follows Beier et al.'s holistic approach and divides the topic into three main areas: organization, people and technology [44].

\subsection{Organization}

\subsubsection{Vision, Strategy, Integration}

Studies show that organizations need clear, measurable and comprehensive objectives and visions for the implementation of Industry 4.0 to have preventive effects on the performance [68]. Additionally, it is essential to encourage the people responsible for project management to focus on Industry 4.0 and to lead the team in a structured and 
orderly manner [68]. To implement Industry 4.0, vertical and horizontal integration is required. Horizontal integration is the connection of the companies to each other in order to coordinate transport routes and networks, through so-called decentralization [39]. Vertical integration connects the hierarchy layers in a company, for example, to create a highly flexible production $[39,69]$ or to optimize processes [70]. Enablers for self-optimizing organizations are flexibility, variability, cognition and autonomy [71] with the aim to track KPIs, for example on energy dashboards used on the shop floor and in offices [50]. When it comes to adopting the paradigm into organizations, sustainability and green supply chains play an important role [72]. Business models and use cases have shown significant potential in energy reduction, decreasing emissions, reducing waste [72-74] and optimizing logistics by implementing networks, sensors and cyber physical systems [75].

\subsubsection{Challenges}

Organizational challenges include decentralization [59], handling of large amounts of data [71,76] and convergence of different data standards to a uniform approach [77]. In addition, high investment costs, a lack of clarity about economic benefits and challenges in value chain integration are other important points [78]. To assist companies with meeting these challenges, authors have done research in the development of maturity and migration models. A well-known and used maturity model is RAMI 4.0 (Reference Architecture Model Industry 4.0), which measures the readiness of industries with regard to the implementations of Industry 4.0 paradigms [79]. The common objective of those models is to transfer knowledge from the theoretical research into companies and provide a related tool for assessing the Industry 4.0 maturity of manufacturing enterprises $[56,80]$. Also, capability models allow the user to assess the current status of their organization within defined levels and decide on further steps. Issa et al. for example distinguished between 4 levels beginning with 'no Industry 4.0 ' up to the 'Inter-organizational level' in their research [81].

\subsubsection{SMEs}

SMEs (Small and Medium sized Enterprises) play a special role in research. They are characterized by their reduced financial possibilities and by the use of the available technologies in smaller circles [82-85]. The main challenges are to identify applications in their processes and to measure the results of the digital solutions [85]. Authors resume that SMEs need special support to leverage potentials of digitization and Industry 4.0 [86]. This is countered by a less complex organizational structure, which makes it easier to implement the identified factors and develop management innovations $[84,87,88]$. Starting with simple practical applications, Magadán et al. introduced their approach by digitizing available structures using sensors and networks, for example by monitoring electric motors in a low-cost real-time approach [89].

\subsubsection{Lean 4.0}

Regardless of size and vision, the principles and methods of the 'Lean-Philosophy' have been consistently adapted and implemented by companies since its introduction. The paradigm shaped organizations by optimizing processes, continuous improvements, reducing errors and implementing preventive methods for quality improvements. With the digital technologies, a convergence between the two paradigms is discussed in the literature. According to several studies, Industry 4.0 is able to support the lean principles respectively so both approaches can support each other [90,91]. Lean principles are still seen as the basis and the mainstay of successful organizations, while Industry 4.0 applications can stabilize and support the principles [60,91-93]. 


\subsection{People}

\subsubsection{The Human Role}

The empirical findings of scientists agree that the human worker will continue to be an important part of the organization and the link between real and virtual assets [94-98]. Digital and smart factories continue to depend on people as key operators rather than becoming unmanned autonomous factories [94,97]. Nevertheless, the focus of the work is changing from the active part towards more passive work such as observation and supervising data and information flows [99]. The challenge will be to structure, summarize and especially interpret the data coming from sensors and autonomous machines [94,95]. In addition to the new practical activities (e.g., network technologies, data processing), workers also need to develop their social skills (e.g., ability act reflective and autonomous) [57]. This requires new human-centric design and engineering philosophies to interact with the cyber physical systems.

\subsubsection{Human-Machine Interaction}

The interconnection or interaction of machines and workers plays an important role [92]. In addition to direct interaction with the machine (H2M, collaborative robots, etc.), virtual interaction can also take place in the form of data verification or creativity. Above a certain level of digitization, it is not possible for workers to take a holistic view of errors. This is where systems must provide support [99]. The resulting socio-technical system contains the human being as the intersection between social (human-centered) and technical (non-human) content [100]. Currently, most articles focus on new technologies and direct collaboration. Badri et al. argues that despite the technological driver, the health and safety of the worker also has a very important role and studies have to be designed to gain further experience in this field [59].

\subsubsection{Learning Factories}

In order to prepare employees on those upcoming challenges, researchers developed so-called learning factories for practical training [50,51,97-99,101-110]. Their aim is to transfer the knowledge of theoretical research into the shop floor and to prepare workers and students. With the paradigm of Industry 4.0, learning factories are a promising approach to competence development and transferring knowledge. Studies focus on finding appropriate learning strategies and create training sessions based on latest trends in manufacturing, research and education in different areas of engineering [101]. Due to current changes in the working environment and the associated increase in home offices, training via online courses is also becoming more popular [111].

\subsection{Technology}

\subsubsection{Enabler of Industry 4.0}

Technologies are seen as enablers of Industry 4.0 and its business models over the whole value chain [112]. In most cases, these are mobile technologies such as the usage of clouds, data analysis, machine-to-machine and human-to-human technologies [113]. Especially in the fields of data analysis and human-machine interaction, breakthroughs have been realized [114]. The main objective of these technologies is the improvement of communication and information flow for data transfer between electronic media [35,115]. Authors have several approaches to structure the technologies, where the goal for example is judged by their output (e.g., virtualization, traceability) or the differentiation between the applications (e.g., Smart Mobility, Smart Products, Smart Machines) [51,112]. Frameworks should not describe the technologies themselves in detail [116,117].

\subsubsection{Key Technologies}

Key technologies have been identified within the literature research. They are briefly presented below and can be summarized as the Internet of Things, Cyber Physical Systems, 
Cloud Computing, Big Data Analysis, Adaptive Robots, Artificial Intelligence, Additive Manufacturing as well as Augmented/Virtual Reality.

The IoT (Internet of Things) refers to a networked world. Machines, mobiles and humans are embedded with electronic sensors, actuators or other digital devices to generate data $[115,118]$. The purpose of this network is to collect, exchange and analyze data for improvements or changes in the environment of the network [35]. Radio-Frequency Identifications (RFIDs) for example can be seen as a key enabler for ubiquitous data management [118].

Cyber Physical Systems (CPS) are mechanisms where physical objects, humans and software are closely intertwined to create new levels of sociotechnical interactions [94,115]. The real world with its physical objects therefore consistently interacts with the virtual world to exchange information and indicate the best decision $[35,118,119]$. In the field of manufacturing, so-called CPPS (cyber physical production systems) are created [109].

Cloud Computing describes the remote computing via wireless networks, whereas services are visualized through scalable resources over the internet $[35,119]$. Moreover, it is characterized through its extremely fast response and the external storage of data, mostly combined with Big Data $[115,118]$.

For analysis of large unstructured, semi-structured and structured data, Big Data Analysis was used. The technology tries to present data in an evaluable way [115] to find patterns [35] and to support decisions [118] or to provide a basis for a decision [120].

In order to implement the technology of cyber physical systems, the human being serves as an interface in a collaboration with machines and robots. Those Adaptive Robots combine worker flexibility with the advantages of robotics $[119,121]$. The robot extends the possibilities of the human [121,122].

Due to the increasing complexity of the systems, it is becoming increasingly difficult to make decisions on the basis of a holistic view. Data structured by Big Data is analyzed with Artificial Intelligence (AI) for further investigation. In several applications, AI has proven to be a key tool when it comes to complex problems involved in demanding applications [123]. The goal of the technology is an intelligent machine that can react in a similar way to human logic [121].

As part of the physical system, in addition to the use of Adaptive Robots, Additive Manufacturing (AM) can be described as a key technology [122]. Also known as 3Dprinting, it is mainly suitable for the individual production of small batch sizes with high complexity [118]. It enables the direct production of digital 3D models and therefore fits into the digital value chain $[118,119]$.

Another key technology is Augmented or Virtual Reality (AR, VR), where reality is supported and mixed by the use of digital 3D models [124,125]. AR is mostly used in the assembly of complex components or as a technical 3D-documentation in real time, often as an aid to predictive maintenance $[125,126]$. Supporting time, errors and cost reduction can be achieved [127].

New emerging technologies such as the 5G technology that has been emerging since 2019 are not key technologies in the bibliometric analysis which covers the past. This time lag of important technologies distorts the current state of the art.

\section{Results of the Bibliometric Analysis}

Among others, bibliometric methods can be used to explore the impact of the field of the publication or the impact of a set of researchers. Bibliometrics does not make any statements about the quality of scientific publications but deals exclusively with their quantities. It is possible to create connections between the documents and display them using graphics [128].

One possible connection is the distributions of the articles to the multiple journals in which they have been published. As done before regarding the present topic, Zhong et al. for example pointed out how present Industry 4.0 is, especially for the manufacturing sector. Leading journals are the 'International Journal of Advanced Manufacturing Tech- 
nology' (83 publications) and the journal 'Computer Integrated Manufacturing Systems' (69) [34]. Within the present research, the distribution slightly changes. Still, while there is a huge predominance of manufacturing journals, there is also a movement to journals such as 'Technological Forecasting \& Social Change' (11, Figure 4). This implies that researchers see Industry 4.0 also as a way to transform the industry towards sustainability and environmentally friendly structures (see Figure 4). Since 2015, Procedia CIRP and Procedia Computer Science and IFAC PapersOnLine covered most of the publications found (Figure 4).

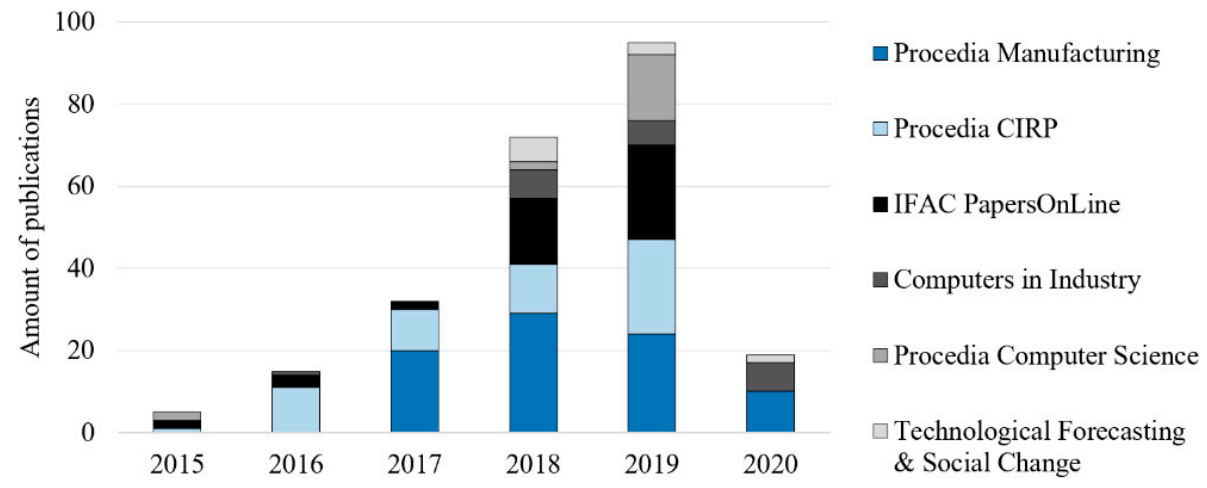

Figure 4. Distribution of publications in different journals (2015-July 2020).

Another possibility of bibliographic analysis involves using keyword analysis, which shows the connected keywords used together. Keywords should describe the publication and, if necessary, classify it into categories. All keywords of the 338 publications were used as the basis for the keyword analysis. As described above, this is $5 \%$ of all publications found. For the analysis, similar spellings were adjusted and summarized. The present keyword network has 883 nodes and 1640 edges. In Figure 5, only keywords with an output value range of 20 or more were considered. The keyword 'Sustainable' also underlines that Industry 4.0 is increasingly moving into the area of sustainability and environmental protection. The keyword 'Learning Factory' is a result of the high number of university publications and the transfer of Industry 4.0 test facilities from research to industry. The open source software Gephi was used to create the network. This software offers different algorithms for the representation of networks. The keyword analysis was created with the provided algorithm 'Force Atlas2' [129].

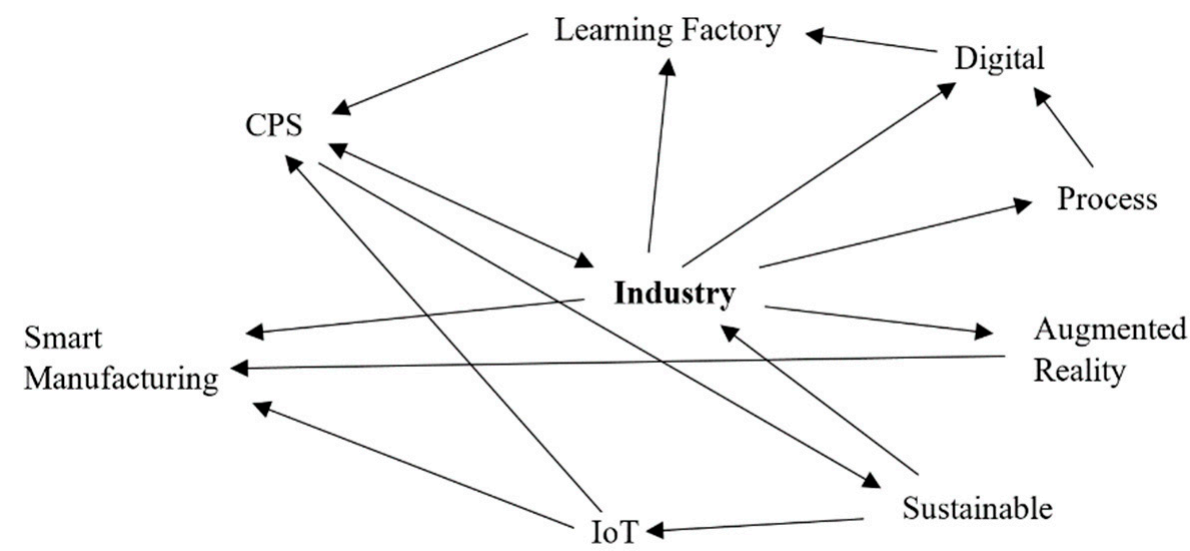

Figure 5. Analysis and relationship of the keywords.

Other authors have done comparable bibliographic analysis on Industry 4.0. Li et al. analyzed individual keyword frequency and the focus of research in literature [130]. The combination of individual words was not considered as well as similar spellings or thematic duplicates (Internet of Things/IoT), but there have been the same results as in the previous 
keyword analysis in Figure 5. Yildiz analyzed the full texts of the publications [131]. Single words like manufacturing and engineering were considered individually and not in context. The result for the years 2012-2015 is similar to the present keyword analysis and to $\mathrm{Li}$ et al. For the years 2016-2018, the number of nouns decreases for unexplained reasons and thus diverges with the other results. Mariani does a very comprehensive bibliometric analysis of the term Industry 4.0 [132]. Parameters such as author, citations, keywords and country of publication have been included. The definition was analyzed in a differentiated way on the basis of several publications. The results did not include keywords or specific qualitative results relevant to this paper. Muhuri examined the search term Industry 4.0 and the influence of individual authors, publishing institutes and journals [133]. As a result, the two most frequent journals for publications were found to be Procedia Manufacturing and Procedia CIRP. Muhuri also completed a keyword analysis and presented it in a similar way. Again, both results are similar, only the number of keywords shown varies (same keywords: Industry 4.0, smart manufacturing, IoT, CPS). The following Table 1 shows a summary of the individual approaches.

Table 1. Approaches of bibliometric analysis within the scope of the literature research.

\begin{tabular}{ccccc}
\hline & Li [130] & Yildiz [131] & Mariani [132] & Muhuri [133] \\
\hline Time period & 2012-2019 & 2012-2018 & 2012-2018* & 2012-2017* \\
\hline $\begin{array}{c}\text { Number of } \\
\text { papers }\end{array}$ & 3.548 & 4.029 & 757 & 1.619 \\
\hline Database & Scopus & Scopus & $\begin{array}{c}\text { Scopus, WoS **, } \\
\text { Google Scholar }\end{array}$ & Scopus, WoS ** \\
Analyze & Keywords & Complete Text & $\begin{array}{c}\text { Authors, Ranking, } \\
\text { Citations }\end{array}$ & $\begin{array}{c}\text { Authors, } \\
\text { Journals, } \\
\text { Keywords }\end{array}$ \\
\hline $\begin{array}{c}\text { Evaluation } \\
\text { software }\end{array}$ & N/A & $\begin{array}{c}\text { Scimat, } \\
\text { VoSviewer }\end{array}$ & $\begin{array}{c}\text { Proprietary software } \\
\text { based on Python }\end{array}$ & VoSviewer \\
\hline Search queue & $\begin{array}{c}\text { Industry 4.0, } \\
\text { Industrie 4.0 }\end{array}$ & Industry 4.0 & $\begin{array}{c}\text { Industry 4.0, } \\
\text { Industrie 4.0, } \\
\text { Industrial } \\
\text { Revolution }\end{array}$ & Industry 4.0 \\
\hline
\end{tabular}

Note: In the forth column, ${ }^{*} 1$ st October, ${ }^{* *}$ Web of Science; In the fifth column, ${ }^{*} 10$ th October, ${ }^{* *}$ Web of Science.

For the present bibliometric analysis, the descriptions found in the 340 publications are used. They have been scanned and extracted by the authors. Definitions in German language were translated into English. If authors cited the descriptions or definitions of others, they were treated as their own opinions. A floating text document $\left({ }^{*} . t x t\right)$ with all found descriptions was created for the analysis using a bibliometric algorithm. Statistical analysis allows for empirical statements about quantitative properties in linguistics such as word frequencies or collocation frequencies. Collocations define a related group of words, which occur statistically significantly more often than by random chance, like 'Industry $4.0^{\prime}$ or 'Industrie 4.0' [134]. The specific length of the collocations was chosen as a group of two to four words. This simple statistical approach enabled analyzing the keyword density without a direct semantic view. Nevertheless, since the algorithm separated each word from the descriptions and its contextual meaning, the method provided a general overview and was able to cluster the most important collocations in the context of Industry 4.0.

Within the 340 analyzed publications, 260 have included definitions whereas 80 do not include any descriptions or definitions in their publications (31\%). One can assume that these authors took the concept as given or that they were not able to define Industry 4.0. Generally, authors using the German term focused more on giving the reader a description, especially in the first years after its introduction (until 2017). The more popular the term was, the less often a proper description was given. In 2019 , nearly $50 \%$ of the authors using the English expression abandoned providing a definition. 
The goal of the bibliometric analysis was to illustrate the collocations for forming a general definition of Industry 4.0 (Figure 6). In almost every definition, the phrases 'Industry 4.0 ' or 'Industrie 4.0 ', respectively and 'Fourth Industrial Revolution' were used as introductory words. In order to show collocations linked to the topic, these phrases are not illustrated in Figure 6.

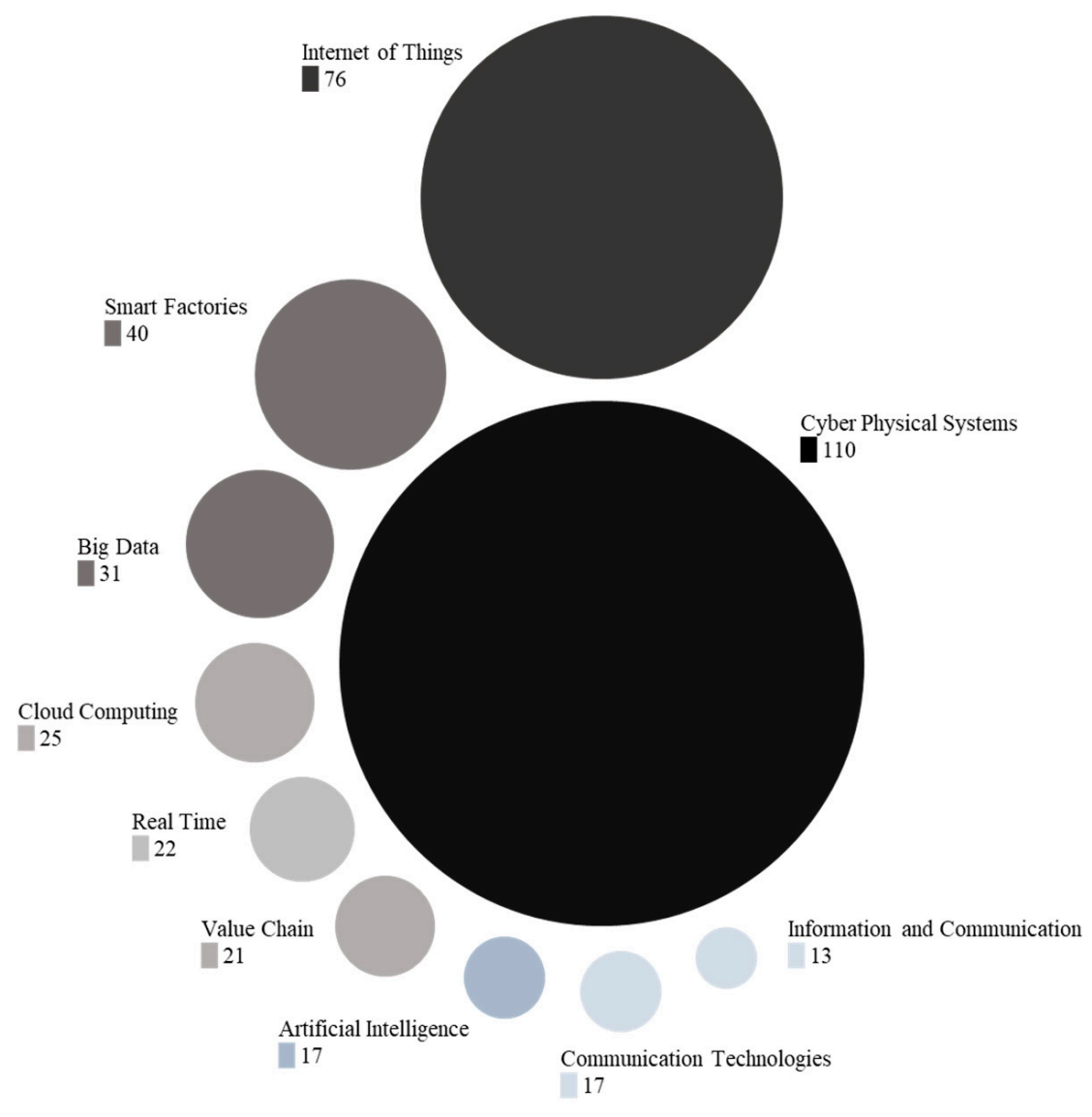

Amount of mentions of all collocations

Figure 6. Overview of the most frequent collocations to define Industry 4.0 in the reviewed literature.

The Cyber Physical System (110) is the most used collocation in relation to describing Industry 4.0. In addition, the Internet of Things (76), Smart Factories (40), Big Data (31) and Cloud Computing (25) are highly used phrases (see Figure 6). Although the main focus of Industry 4.0 is the manufacturing sector, phrases like 'Production Processes' (12), 'Manufacturing Industry' (12) and 'Manufacturing Systems' (11) are used less often.

\section{Forming a New Definition}

As shown above, currently there is no definition for the term "Industry 4.0 ". For the definition, the top 10 collocations from the analysis as shown in Figure 6 were considered. The publications used for the analysis describe the term or find a definition for their application / business area. The aim was to form a concise definition from all these explanations. Therefore, the top 10, the most important ones, were taken to form a sentence. The aim of writing a sentence was to avoid generating another description of the term. Due to the interchangeability of the collocations, multiple orders for the definition itself are possible. The definition was structured by the numerical appearance of collocations starting with the most frequent used collocation (Cyber Physical Systems, 110), which is also the key component of this definition. Influenced by the approach of the extensional definition, the authors developed a possible definition starting with the paradigm of 'Industry 4.0': 
"Industry 4.0 is the implementation of Cyber Physical Systems for creating Smart Factories by using the Internet of Things, Big Data, Cloud Computing, Artificial Intelligence and Communication Technologies for Information and Communication in Real Time over the Value Chain."

In this order, the definition covers the paradigm (Industry 4.0), what it is (implementation of Cyber Physical Systems), why it is necessary (creating Smart Factories [...] for Information and Communication in Real Time over the Value Chain) and how it is done (by using the Internet of Things, Big Data, Cloud Computing, Artificial Intelligence and Communication Technologies). The definition aims to cover all aspects regarding the information (creation, sharing, transfer and storage).

\section{Discussion}

The Industry 4.0 paradigm and its technologies are transforming the economy and its production. While from the customer's point of view ever shorter product life cycles demand faster innovation, this can be solved by organizations through technologies, networking and open innovation [11]. A standardization [10] or a definition of Industry 4.0 would lead to a more focused research as well as a better framework for implementation in companies. However, there is no definition available yet $[11,45,46]$. Commonly, definitions enable an objective understanding of a phrase and create value beyond its intended purpose of describing something effectively [16]. Results show that the absence of a clear definition of Industry 4.0 leads to a loss of confidence in understanding this term [43] and to a restriction of its usage [63]. In addition to a scientifically sound definition, this reflects the understanding of the term Industry 4.0 in other aspects such as morality, sustainability and social-economic aspects. Therefore, a conscious attempt was made to pursue an objective and unbiased approach. Case studies, which would contribute to understanding but also subjectively distort the term, have been avoided. Instead, a definition was formed using statistical word analysis. All the analyzed publications form a definition and contribute to it individually. The informative value of the analysis was limited by a number of factors. The understanding of the term was based exclusively on the literature on Industry 4.0, derived from only one database and one search term variating in the German and English languages. Only articles published in ScienceDirect were used for the data collection [30]. The inclusion of search results from other databases, a larger number of publications or related terms such as Internet of Things may enrich the understanding of the concept and could lead to a better representation of the aspects mentioned above. This was already recommended by Beier in the area of sustainability [44]. The limitation reduces the objectivity of the results, but in a first step it shows a novelty definition that can be further developed by adding other databases such as Scopus in $[130,131]$ or Google Scholar and Web of Science in [132]. The interdisciplinary scientific work found in this expansion also would increase the objectivity of the definition. Nevertheless, with the ScienceDirect database, a technical and objective definition could be obtained. This is also evident in the literary comparison with the bibliometric analysis already carried out. Muhuri et al. [133] as well as Zhong et al. [35] came up with similar results in the keyword analysis using different databases such as Google Scholar, Web of Science and Scopus. In all three databases, the main words are Industry 4.0, cyber physical systems, Internet of Things and smart manufacturing. Some of the journals in ScienceDirect can also be found in the Web of Science and Scopus databases (e.g., Procedia CIRP, Computers in Industry). Despite a certain scepticism towards the introduced definition, the comparisons with other results show that it is valid and justifiable.

The challenge of a general definition also lies in the nomenclature of publications. Current research identifies different terms of Industry 4.0 [35]. This makes general structuring more difficult and increases the risk of misjudging essential keywords. This might result on a focus in technical reviews such as Zhong et al. [35] or Culot et al. [42]. Additionally, the authors noticed in the structure of the existing publications that the human perspective is less focused. Here it is mainly about learning factories [102,103]. The clear technological 
orientation of Industry 4.0 can be seen [112]. The authors agree with this analysis but point out that humans are a key part of the paradigm. Therefore, the focus should be lightened. This analysis might also shift with a wider database and an expansion of the search words. As shown in the analysis of the most relevant journals, the composition of the top five is constantly changing. As an example, the journal 'Technological Forecasting \& Social Change' has become more and more in focus in recent years (see Figure 4). The trend of taking social facets into account has also been shown in the literature review. Even if there is a lack of knowledge, the human role is becoming more important and science is working with great interest in learning factories.

The bibliometric analysis shows the frequency of the individual collocations in a technical-oriented perspective, but not the order or even a finished definition. In the creation of the definition, the choice of the composition in the order of the words does not follow any scheme, but is chosen freely and meaningfully. The authors have subordinated the order to the goal of forming one coherent and logical sentence. This can also be solved in another context by using several sentences. A definition of the most frequently found collocations can also be seen as a definition. However, this increasingly shifts the boundary of a definition towards a description.

Within the 340 analyzed publications, 80 do not include any descriptions or definitions in their publications (31\%). One can assume that these authors take the concept as given or that they have not been able to define Industry 4.0. Therefore, it is clear that subjective opinions of the authors have been included in the new definition, even if this was prevented by methodology. For this purpose, the link between the words in the definition was represented by their frequency. Within the 10 most frequently found collocations, a technology-heavy trend can be seen. Only 'Real Time' and 'Value Chain' do not represent this trend. In addition, there are large differences in the frequency of the mentions. Cyber physical system $[94,118,119]$ was mentioned 110 times, while Internet of Things $[115,118]$ was mentioned 76 times. The gap to the next most frequent collocation, Smart Factories (40 mentions), was large. The authors point out that they could alternatively reach a very short definition of Industry 4.0 by only naming these two collocations.

Methodological aspects are usually overlooked due to a lack of definition and the purely theoretical development that goes along with it. This was criticized by Culot and discussed despite the lack of a clear definition [42]. The benefits from this present work could establish and describe the paradigm for further implementation and acceptance in theory and practical environments, as was also criticized in [15]. Due to the fastemerging field of digitization and upcoming technologies, the proposed definition will likely be adopted, variated or changed over time. It has to be considered as valid for a limited time and as steadily changing, especially in the beginning of Industry 4.0. If the necessary conditions are fulfilled, the definition has to be adjusted properly based on future publications. Due to the complexity of the subject matter and the ongoing progress in technology, such a bibliometric analysis should be done frequently. In this way, the definition can be adapted to current developments and industry users understand the term. It lowers the barriers for private individuals or industrial companies to enter the Industry 4.0 sector.

\section{Examples and Validation}

The four following examples are shown to evaluate the introduced definition. To guarantee a broad validation, publications besides the manufacturing sector were excluded. Those publications are already mentioned above and are settled in the fields of construction, food, medicine and supply chains.

Oesterreich and Teuteberg adopted the implications of digitization to the construction industry [17]. Besides their systematic literature research, they pointed out the benefits of Industry 4.0 for the construction industry. Many tools and technologies have reached market maturity and could be used to digitize the construction industry. Those would be economic benefits like cost and time savings, advantages for workers such as higher safety 
and better representation like an improved Customer-Relationship-Management and an improving sustainability. Additionally, challenges and problems are identified and summarized. Within the approach to link the definition with the construction industry, smart factories are substituted by smart buildings, whereas the IoT, Big Data and communication technologies remain the same. Oesterreich and Teuteberg pointed out that the key features for implementing Industry 4.0 in the construction area are the horizontal integration through value networks, which are similar to the goal of the introduced definition.

In the next case, the Luque et al. analyze the food sector regarding Industry 4.0 through literature research. Therefore, the scope of the research includes planting, harvesting, processing, producing as well as selling and serving food [18]. Technologies always have been a main driver in the food sector to increase growth rates and sustainable packaging and delivering. Although some technologies have not matured yet, the developments of the IoT, Cloud Computing, Big Data and cybersecurity led to a massive change in the food supply chain. Those technologies also are the main drivers in the introduced definition. As the maturity in the food sector has not yet been reached, the entire value chain cannot be networked yet. Although the definition can be applied here, it should be understood in a more future-oriented way.

The next example is about Industry 4.0 and its application of design principles on the future health system [19]. Therefore, Health 4.0 acts as a buzzword to cover the new trends and concepts of the industry, which includes personalization and the care in real time by using smart devices. Thuemmler et al. argue that an intensive use of cyber physical systems, cloud computing, the internet of everything as well as mobile communication networks are the enabler of these new design principles. In context to the introduced definition, the value chain is represented by the treatment of the patient, which is transformed by those new technologies. As if the introduced definition slightly focuses on the production industry (smart factories), the concept of Health 4.0 implements a virtual treatment room as a service. As a result, the definition of Industry 4.0 also is applicable to services.

For the convergence between supply chain management and Industry 4.0, Tjahnono et al. analyzed the impact of the digital technologies on the value chain as a whole [22]. Even if there are only a few practical examples on the impact of Industry 4.0 on the supply chain management, it is considered that there is a change in the way that companies structure and organize themselves. In particular, technologies like the IoT and Radio-frequency identification (RFID) affect the organization and its information and communication systems. This implies that the introduced definition could be adopted to the area of supply chain management as well. Within the adoption, the focus changes from the creation of a cyber physical system towards the communication in real time over the value chain. Nevertheless, cyber physical systems are created by adding RFID-Tags on the physical products.

\section{Summary and Conclusions}

Industry 4.0 is understood by many as a vision, a concept or a paradigm. Even though the term Industry 4.0 is not defined yet, it is used in headlines, keywords and abstracts to gain attention as a buzzword. Objects and projects often are named after the suffix ' 4.0 '. This shows the attention experts are giving to the paradigm and its concepts. Due to the lack of a uniform understanding of 'Industry 4.0 ', the present paper aims to create a technologicaloriented definition by doing a bibliometric analysis of 340 publications in the database of ScienceDirect. The literature was classified by a review into the fields of organization, human and technology. Per the aforementioned methodology, a bibliometric approach was used to analyze the plain text fragments. The missing semantics led to inaccuracies such as multiple mentions of keywords in one description. In addition, several authors referred to and cited descriptions of other publications regarding the German government's 'Platform Industrie 4.0' [135]. Nevertheless, the definition describes the scope and mentions the paradigm, its necessity and its way of implementation. The definition was tested and successfully validated on four examples from different professional areas (construction, food sector, health system, supply chain management). 
The key results of the present research are:

- Many authors do not focus on a definition or description of Industry 4.0 in their publications. On the one hand, the term might be seen as implicitly understood; on the other hand, there is no clear and holistic definition available. Moreover, they describe Industry 4.0 as an umbrella term, concept or vision.

- The literature review shows the focus on key technologies and the lack of research in a worker environment. This trend was increased by the selection of the technologicaloriented database. However, a trend towards compensating for these deficits is recognizable in the appearance of the journals in which the articles were published.

- The top three collocations are on Cyber Physical Systems, the Internet of Things and smart factories. This shows a very technological direction, which was to be expected due to the selected database.

- Within the methodology, the definition of Industry 4.0 is as follows: 'Industry 4.0 could be defined as the implementation of Cyber Physical Systems for creating Smart Factories by using the Internet of Things, Big Data, Cloud Computing, Artificial Intelligence and Communication Technologies for Information and Communication in Real Time over the Value Chain.'

- The definition successfully was tested and validated on four examples from different professional areas such as construction, food, health system and supply chain management.

In the authors' opinion, further research can lead in two basic directions. First, the database should be expanded alongside the existing ScienceDirect database. This expansion would make the definition of Industry 4.0 more interdisciplinary and more valid due to increased data volumes. The technological orientation would thus be able to give way to a broad and generally valid definition. The authors suggest basing the further selection of databases on analyses already carried out by Li, Yildiz and Mariani and Muhuri [130-133]. They used Scopus, Web of Science and Google Scholar.

Second, an intelligent algorithm or Artificial Intelligence can be used to search for the description or definition of the authors within their publication. Artificial Intelligence also is able to analyze the extracted text fragments. Especially with the combination of semantic and trained artificial neuronal networks, the scope of analysis could be extended to give a more precise and detailed overview [136]. Artificial Intelligence makes it possible to analyze semantic data faster and more objectively [137]. In particular, the order of words and their connection to the whole description within a publication could help to develop another statistically more secure definition than the present work. In a next step, a given algorithm can thus be compared with the results of the presented definition on a small scale.

Despite the success of the present analysis, the term 'Industry $4.0^{\prime}$ will have to be monitored in the future. As discussed before, due to the rapid developments through open innovation, a valid definition can only be guaranteed through equally frequent validation, new data collection and adjustments of the definition. As proposed, further analysis for more extensive and semantic-including definitions needs to be conducted. This effort might lead to more precise definitions and strengthen the position and implementation of Industry 4.0.

Author Contributions: Conceptualization, M.R.; methodology, M.R. and M.S.; software, M.R. and M.S.; validation, M.R. and M.S.; formal analysis, M.R. and M.S.; investigation, M.R. and M.S.; resources, M.R. and M.S.; data curation, M.R. and M.S.; writing—original draft preparation, M.R. and M.S.; writing-review and editing, M.M., R.B. and Harrison, D.K.H.; visualization, M.R. and M.S.; supervision, M.M., R.B. and Harrison, D.K.H.; project administration, M.M., R.B. and D.K.H.; funding acquisition, M.S. All authors have read and agreed to the published version of the manuscript.

Funding: This research was funded by the Federal Ministry of Education and Research, grant number 13FH003IB6. The APC was funded by the Institute of Virtual Product Development, Aalen University.

Institutional Review Board Statement: Not applicable. 
Informed Consent Statement: Not applicable.

Data Availability Statement: Data available in a publicly accessible repository.

Conflicts of Interest: The authors declare no conflict of interest.

\section{References}

1. Deppe, K. Geschichte der Arbeit-Arbeit 4.0. Arbeitsgemeinschaft der Öffentlich-Rechtlichen Rundfunkanstalten der Bundesrepublik Deutschland. 2019. Available online: https://www.planet-wissen.de/gesellschaft/arbeit/die_geschichte_der_arbeit_und_was_ sie_heute_bedeutet/arbeit-vier-punkt-null-100.html (accessed on 23 October 2020).

2. Kagermann, H.; Wahlster, W.; Helbig, J. Umsetzungsempfehlungen für das Zukunftsprojekt Industrie 4.0. Available online: https://www.bmbf.de/files/Umsetzungsempfehlungen_Industrie4_0.pdf (accessed on 10 November 2020).

3. Scharlack, U. Industrie 4.0. BMBF. 2019. Available online: https://www.bmbf.de/de/zukunftsprojekt-industrie-4-0-848.html (accessed on 20 November 2020).

4. Schwab, K. The Fourth Industrial Revolution. World Economic Forum. 2016. Available online: https://www.weforum.org/ agenda/2016/01/the-fourth-industrial-revolution-what-it-means-and-how-to-respond/ (accessed on 27 October 2020).

5. Andrews, D.; Criscuolo, C.; Gal, P. The Best versus the Rest: The Global Productivity Slowdown, Divergence across Firms and the Role of Public Policy. OECD Productivity Working Papers. 2019. Available online: https://www.oecd.org/going-digital/ productivity-growth-in-the-digital-age.pdf (accessed on 1 December 2020).

6. Mubarak, M.F.; Petraite, M. Industry 4.0 technologies, digital trust and technological orientation: What matters in open innovation? Technol. Forecast. Soc. Chang. 2020, 161, 120332. [CrossRef]

7. Travaglioni, M.; Ferazzoli, A.; Petrillo, A.; Cioffi, R.; De Felice, F.; Piscitelli, G. Digital manufacturing challenges through open innovation perspective. Procedia Manuf. 2020, 42, 165-172. [CrossRef]

8. Sag, S.; Sezen, B.; Alpkan, L. Determinants of Open Innovation and their Interrelations. Int. J. Innov. Technol. Manag. 2018, 16, 1940001. [CrossRef]

9. Hizam-Hanafiah, M.; Soomro, M.A. The Situation of Technology Companies in Industry 4.0 and the Open Innovation. J. Open Innov. Technol. Mark. Complex. 2021, 7, 34. [CrossRef]

10. Urbinati, A.; Davide, C.; Vittorio, C.; Federico, F. The role of digital technologies in open innovation processes: An explanatory multiple case study analysis. $R$ D Manag. 2018, 50, 136-160. [CrossRef]

11. Lee, M.; Yun, J.J.; Pyka, A.; Won, D.; Kodama, F.; Schiuma, G.; Park, H.; Jeo, J.; Park, K.; Jung, K.; et al. How to Respond to the Fourth Industrial Revolution or the Second Information Technology Revolution? Dynamic New Combinations between Technology, Market, and Society through Open Innovation. J. Open Innov. Technol. Mark. Complex. 2021, 4, 21. [CrossRef]

12. Zezulka, F.; Marcon, P.; Bradac, Z.; Arm, J.; Benesl, T.; Vesely, I. Communication Systems for Industry 4.0 and the IIoT. IFAC-Pap. 2018, 51, 150-155. [CrossRef]

13. Ayatollahi, I.; Brier, J.; Mörzinger, B.; Heger, M.; Bleicher, F. SOA on Smart Manufacturing Utilities for Identification, Data Access and Control. Procedia CIRP 2018, 67, 162-166. [CrossRef]

14. Arnold, C.; Kiel, D.; Voigt, K.-I. Innovative Business Models for the Industrial Internet of Things. Bhm Berg- Und Hüttenmännische Mon. 2017, 162, 371-381. [CrossRef]

15. Jeske, T.; Lennings, F.; Stowasser, S. Industrie 4.0-Umsetzung in der deutschen Metall- und Elektroindustrie. Z. Arb. Wiss. 2016, 70, 115-125. [CrossRef]

16. Hurley, P. A Concise Introduction to Logic 2008, 10th ed.; Thomson Wadsworth: California, CA, USA, 2007; ISBN 978-0495503835.

17. Oesterreich, T.D.; Teuteberg, F. Understanding the implications of digitisation and automation in the context of Industry 4.0: A triangulation approach and elements of a research agenda for the construction industry. Comput. Ind. 2016, 83, 121-139. [CrossRef]

18. Luque, A.; Peralta, M.E.; las Heras, A.D.; Córdoba, A. State of the Industry 4.0 in the Andalusian food sector. Procedia Manufa. 2017, 13, 1199-1205. [CrossRef]

19. Thuemmler, C.; Bai, C. Health 4.0: Application of Industry 4.0 Design Principles in Future Asthma Management. In Health 4.0: How Virtualization and Big Data Are Revolutionizing Healthcare; Springer: Cham, Switzerland, 2017; Volume 372, pp. $23-37$.

20. Javaid, M.; Haleem, A. Industry 4.0 applications in medical field: A brief review. Curr. Med. Res. Pract. 2019, 9, 102-109. [CrossRef]

21. Ivanov, D.; Dolgui, A.; Sokolov, B.; Werner, F.; Ivanova, M. A dynamic model and an algorithm for short-term supply chain scheduling in the smart factory industry 4.0. Int. J. Prod. Res. 2016, 54, 386-402. [CrossRef]

22. Tjahjono, B.; Esplugues, C.; Ares, E.; Pelaez, G. What does Industry 4.0 mean to Supply Chain? Procedia Manuf. 2017, 13, 1175-1182. [CrossRef]

23. Braun, A.-T.; Colangelo, E.; Steckel, T. Farming in the Era of Industrie 4.0. Procedia CIRP 2018, 72, 979-984. [CrossRef]

24. Barreto, L.; Amaral, A.; Pereira, T. Industry 4.0 implications in logistics: An overview. Procedia Manuf. 2017, 13, 1245-1252. [CrossRef]

25. Hofmann, E.; Rüsch, M. Industry 4.0 and the current status as well as future prospects on logistics. Comput. Ind. 2017, 89, 23-34. [CrossRef] 
26. Jun, S.-P.; Yoo, H.S.; Choi, S. Ten years of research change using Google Trends: From the perspective of big data utilizations and applications. Technol. Forecast. Soc. Chang. 2018, 130, 69-87. [CrossRef]

27. Chumnumpan, P.; Shi, X. Understanding new products' market performance using Google Trends. Australas. Mark. J. 2019, 27, 91-103. [CrossRef]

28. Preis, T.; Moat, S. Adaptive nowcasting of influenza outbreaks using Google search. R. Soc. Open Sci. 2014, 1, 140095. [CrossRef]

29. ScienceDirect.com Science, Health and Medical Journals, Full Text Articles and Books. ScienceDirect. 2019. Available online: https: / / www.sciencedirect.com/ (accessed on 27 August 2020).

30. Elsevier What Is the Difference between ScienceDirect and Scopus Data. 2020. Available online: https://service.elsevier.com/ app/answers/detail/a_id/28240/supporthub/agrm/p/15838/ (accessed on 8 October 2020).

31. Elsevier What Does "Relevance" Mean in Science Direct. ScienceDirect Support Center. 2019. Available online: https: //service.elsevier.com/app/answers/detail/a_id/28453/supporthub/sciencedirect/kw/sort+by/track/APNNygrMDv8a \{\} ZB5Guka \{\}yCgiP8qTy75Mv_F \{\}zj \{\}PP9M/ (accessed on 8 October 2020).

32. Israel, G. Determining Sample Size. University of Florida Cooperative Extension Service. Institute of Food and Agriculture Sciences. 1992. Available online: https://www.psycholosphere.com/DeterminingsamplesizebyGlenIsrael.pdf (accessed on 12 January 2021).

33. Williams, R.; Bornmann, L. Sampling issues in bibliometric analysis. J. Informetr. 2016, 10, 1225-123223. [CrossRef]

34. Stock, T.; Seliger, G. Opportunities of Sustainable Manufacturing in Industry 4.0. Procedia CIRP 2016, 40, 536-541. [CrossRef]

35. Zhong, R.Y.; Xu, X.; Klotz, E.; Newman, S.T. Intelligent Manufacturing in the Context of Industry 4.0: A Review. Engineering 2017, 3, 616-630. [CrossRef]

36. Toro, C.; Barandiaran, I.; Posada, J. A Perspective on Knowledge Based and Intelligent Systems Implementation in Industrie 4.0. Procedia Computsci. 2015, 60, 362-370. [CrossRef]

37. Masood, T.; Sonntag, P. Industry 4.0: Adoption challenges and benefits for SMEs. Comput. Ind. 2020, 121, 103261. [CrossRef]

38. Kuo, C.-C.; Shyu, J.Z.; Ding, K. Industrial revitalization via industry 4.0-A comparative policy analysis among China, Germany and the USA. Glob. Transit. 2019, 1, 3-14. [CrossRef]

39. Tupa, J.; Simota, J.; Steiner, F. Aspects of Risk Management Implementation for Industry 4.0. Procedia Manuf. 2017, 11, 1223-1230. [CrossRef]

40. Qin, J.; Liu, Y.; Grosvenor, R. A Categorical Framework of Manufacturing for Industry 4.0 and Beyond. Procedia CIRP 2016, 52, 173-178. [CrossRef]

41. Kamble, S.S.; Gunasekaran, A.; Gawankar, S.A. Sustainable Industry 4.0 framework: A systematic literature review identifying the current trends and future perspectives. Process Saf. Environ. 2018, 117, 408-425. [CrossRef]

42. Culot, G.; Nassimbeni, G.; Orzes, G.; Sartor, M. Behind the definition of Industry 4.0: Analysis and open questions. Int. J. Prod. Econ. 2020, 226, 107617. [CrossRef]

43. Bigliardi, B.; Bottani, E.; Casella, G. Enabling technologies, application areas and impact of industry 4.0: A bibliographic analysis. Procedia Manuf. 2020, 42, 322-326. [CrossRef]

44. Beier, G.; Ullrich, A.; Niehoff, S.; Reißig, M.; Habich, M. Industry 4.0: How it is defined from a sociotechnical perspective and how much sustainability it includes-A literature review. J. Clean. Prod. 2020, 259, 120856. [CrossRef]

45. Piccarozzi, M.; Aquilani, B.; Gatti, C. Industry 4.0 in Management Studies: A Systematic Literature Review. Sustainability 2018, 10, 3821. [CrossRef]

46. Kiangala, K.S.; Wang, Z. An Industry 4.0 approach to develop auto parameter configuration of a bottling process in a small to medium scale industry using PLC and SCADA. Procedia Manuf. 2019, 35, 725-730. [CrossRef]

47. Buer, S.-V.; Fragapane, G.I.; Strandhagen, J.O. The Data-Driven Process Improvement Cycle: Using Digitalization for Continuous Improvement. IFAC-Pap. 2018, 51, 1035-1040. [CrossRef]

48. Paravizo, E.; Chaim, O.C.; Braatz, D.; Muschard, B.; Rozenfeld, H. Exploring gamification to support manufacturing education on industry 4.0 as an enabler for innovation and sustainability. Procedia Manuf. 2018, 21, 438-445. [CrossRef]

49. Shafiq, S.I.; Sanin, C.; Szczerbicki, E.; Toro, C. Virtual Engineering Object / Virtual Engineering Process: A specialized form of Cyber Physical System for Industrie 4.0. Procedia Comput. Sci. 2015, 60, 1146-1155. [CrossRef]

50. Faller, C.; Feldmüller, D. Industry 4.0 Learning Factory for regional SMEs. Procedia CIRP 2015, 32, 88-91. [CrossRef]

51. Weyer, S.; Schmitt, M.; Ohmer, M.; Gorecky, D. Towards Industry 4.0-Standardization as the crucial challenge for highly modular, multi-vendor production systems. IFAC-Pap. 2015, 48, 579-584. [CrossRef]

52. Long, F.; Zeiler, P.; Bertsche, B. Modelling the production systems in industry 4.0 and their availability with high-level Petri nets. IFAC-Pap. 2016, 49, 145-150. [CrossRef]

53. Motyl, B.; Baronio, G.; Uberti, S.; Speranza, D.; Filippi, S. How will Change the Future Engineers' Skills in the Industry 4.0 Framework? A Questionnaire Survey. Procedia Manuf. 2017, 11, 1501-1509. [CrossRef]

54. Zezulka, F.; Marcon, P.; Vesely, I.; Sajdl, O. Industry 4.0-An Introduction in the phenomenon. IFAC-Pap. 2016, 49, 8-12. [CrossRef]

55. Davies, R.; Coole, T.; Smith, A. Review of Socio-technical Considerations to Ensure Successful Implementation of Industry 4.0. Procedia Manuf. 2017, 11, 1288-1295. [CrossRef]

56. Schumacher, A.; Erol, S.; Sihn, W. A Maturity Model for Assessing Industry 4.0 Readiness and Maturity of Manufacturing Enterprises. Procedia CIRP 2016, 52, 161-166. [CrossRef] 
57. Erol, S.; Jäger, A.; Hold, P.; Ott, K.; Sihn, W. Tangible Industry 4.0: A Scenario-Based Approach to Learning for the Future of Production. Procedia CIRP 2016, 54, 13-18. [CrossRef]

58. Arm, J.; Zezulka, F.; Bradac, Z.; Marcon, P.; Kaczmarczyk, V.; Benesl, T.; Schroeder, T. Implementing Industry 4.0 in Discrete Manufacturing. Options and Drawbacks. IFAC-Pap. 2018, 51, 473-478. [CrossRef]

59. Badri, A.; Boudreau-Trudel, B.; Souissi, A. Occupational health and safety in the industry 4.0 era. A cause for major concern? Saf. Sci. 2018, 109, 403-411. [CrossRef]

60. Bauer, H.; Brandl, F.; Lock, C.; Reinhart, G. Integration of Industrie 4.0 in Lean Manufacturing Learning Factories. Procedia Manuf. 2018, 23, 147-152. [CrossRef]

61. Ribeiro da Silva, E.; Shinohara, A.; Lima, E.; Angelis, J.; Machado, C. Reviewing Digital Manufacturing concept in the Industry 4.0 paradigm. Procedia CIRP 2019, 81, 240-245. [CrossRef]

62. Meissner, H.; Ilsen, R.; Aurich, J. Analysis of Control Architectures in the Context of Industry 4.0. Procedia CIRP 2017, 62, 165-169. [CrossRef]

63. Müller, F.; Jaeger, D.; Hanewinkel, M. Digitization in wood supply-A review on how Industry 4.0 will change the forest value chain. Comput. Electron. Agr. 2019, 162, 206-218.

64. Bai, C.; Dallasega, P.; Orzes, G.; Sarkis, J. Industry 4.0 technologies assessment: A sustainability perspective. Int. J. Prod. Econ. 2020, 229, 107776. [CrossRef]

65. Angelopoulou, A.; Mykoniatis, K.; Boyapati, N. Industry 4.0: The use of simulation for human reliability assessment. Procedia Manuf. 2020, 42, 296-301. [CrossRef]

66. Zeng, P.; Wang, Z.; Jia, Z.; Kong, L.; Li, D.; Jin, X. Time-slotted software-defined Industrial Ethernet for real-time Quality of Service in Industry 4.0. Future Gener. Comp. Syst. 2019, 99, 1-10. [CrossRef]

67. Benitez, G.; Ayala, N.; Frank, A. Industry 4.0 innovation ecosystems: An evolutionary perspective on value cocreation. Int. J. Prod. Econ. 2020, 228, 107735. [CrossRef]

68. Müller, J. Assessing the barriers to Industry 4.0 implementation from a workers' perspective. IFAC-Pap. 2019, 52, $2189-2194$.

69. Long, F.; Zeiler, P.; Bertsche, B. Modelling the flexibility of production systems in Industry 4.0 for analysing their productivity and availability with high-level Petri nets. IFAC-Pap. 2017, 50, 5680-5687. [CrossRef]

70. Pereira, M.; Silva, A.; Ferreira, L.P.; Sá, J.; Silva, F. A DMS to Support Industrial Process Decision-Making: A contribution under Industry 4.0. Procedia Manuf. 2019, 38, 613-620. [CrossRef]

71. Brettel, M.; Fischer, F.; Bendig, D.; Weber, A.; Wolff, B. Enablers for Self-optimizing Production Systems in the Context of Industrie 4.0. Procedia CIRP 2016, 41, 93-98. [CrossRef]

72. Man, J.; Strandhagen, J. An Industry 4.0 Research Agenda for Sustainable Business Models. Procedia CIRP 2017, 63, 721-726. [CrossRef]

73. Tiwari, K.; Khan, M. Sustainability accounting and reporting in the industry 4.0. J. Clean. Prod. 2020, 258, 120783. [CrossRef]

74. Yadav, G.; Kumar, A.; Luthra, S.; Garza-Reyes, J.; Kumar, V.; Batista, L. A framework to achieve sustainability in manufacturing organisations of developing economies using industry 4.0 technologies' enablers. Comput. Ind. 2020, 122, 103280. [CrossRef]

75. Henao-Hernández, I.; Solano-Charris, E.; Muñoz-Villamizar, A.; Santos, J.; Henríquez-Machado, R. Control and monitoring for sustainable manufacturing in the Industry 4.0: A literature review. IFAC-Pap. 2019, 52, 195-200.

76. Villalobos, K.; Ramírez-Durán, V.; Diez, B.; Blanco, J.; Goñi, A.; Illarramendi, A. A three level hierarchical architecture for an efficient storage of industry 4.0 data. Comput. Ind. 2020, 12, 103257. [CrossRef]

77. Schleipen, M.; Gilani, S.; Bischoff, T.; Pfrommer, J. OPC UA \& Industrie 4.0-Enabling Technology with High Diversity and Variability. Procedia CIRP 2016, 57, 315-320.

78. Raj, A.; Dwivedi, G.; Sharma, A.; Lopes de Sousa Jabbour, A.; Rajak, S. Barriers to the adoption of industry 4.0 technologies in the manufacturing sector: An inter-country comparative perspective. Int. J. Prod. Econ. 2020, 224, 107546.

79. Lucato, W.; Pacchini, A.; Facchini, F.; Mummolo, G. Model to evaluate the Industry 4.0 readiness degree in Industrial Companies. IFAC-Pap. 2019, 52, 1808-1813.

80. Leineweber, S. Concept for an evolutionary maturity based Industrie 4.0 migration model. Procedia CIRP 2018, 72, 404-409.

81. Issa, A.; Hatiboglu, B.; Bildstein, A.; Bauernhansl, T. Industrie 4.0 roadmap: Framework for digital transformation based on the concepts of capability maturity and alignment. Procedia CIRP 2018, 72, 973-978.

82. Taurino, T.; Villa, A. A method for applying Industry 4.0 in Small Enterprises. IFAC-Pap. 2019, 52, 439-444.

83. Villa, A.; Taurino, T. SME Innovation and Development in the Context of Industry 4.0. Procedia Manuf. 2019, 39, 1415-1420. [CrossRef]

84. Wienbruch, T.; Leineweber, S.; Kreimeier, D.; Kuhlenkötter, B. Evolution of SMEs towards Industrie 4.0 through a scenario based learning factory training. Procedia Manuf. 2018, 23, 141-146. [CrossRef]

85. Kolla, S.; Minufekr, M.; Plapper, P. Deriving essential components of lean and industry 4.0 assessment model for manufacturing SMEs. Procedia CIRP 2019, 81, 753-758. [CrossRef]

86. Lentes, J.; Zimmermann, N.; Hertwig, M. Industrie 4.0-Scouts Programme. IFAC-Pap. 2019, 52, 445-450. [CrossRef]

87. Horváth, D.; Szabó, R.Z. Driving forces and barriers of Industry 4.0: Do multinational and small and medium-sized companies have equal opportunities? Technol. Forecast. Soc. Chang. 2019, 146, 119-132. [CrossRef]

88. Niemeyer, C.L.; Gehrke, I.; Müller, K.; Küsters, D.; Gries, T. Getting Small Medium Enterprises started on Industry 4.0 using retrofitting solutions. Procedia Manuf. 2020, 45, 208-214. [CrossRef] 
89. Magadán, L.; Suárez, F.J.; Granda, J.C.; García, D.F. Low-cost real-time monitoring of electric motors for the Industry 4.0. Procedia Manuf. 2020, 42, 393-398. [CrossRef]

90. Mrugalska, B.; Wyrwicka, M.K. Towards Lean Production in Industry 4.0. Procedia Eng. 2017, 182, 466-473. [CrossRef]

91. Wagner, T.; Herrmann, C.; Thiede, S. Industry 4.0 Impacts on Lean Production Systems. Procedia CIRP 2017, 63, 125-131. [CrossRef]

92. Prinz, C.; Kreggenfeld, N.; Kuhlenkötter, B. Lean meets Industrie 4.0-a practical approach to interlink the method world and cyber-physical world. Procedia Manuf. 2018, 23, 21-26. [CrossRef]

93. Rossini, M.; Costa, F.; Staudacher, A.P.; Tortorella, G. Industry 4.0 and Lean Production: An empirical study. IFAC-Pap. 2019, 52, 42-47. [CrossRef]

94. Kadir, B.A.; Broberg, O.; Conceição, C.S. Current research and future perspectives on human factors and ergonomics in Industry 4.0. Comput. Ind. Eng. 2019, 137, 106004. [CrossRef]

95. Prinz, C.; Morlock, F.; Freith, S.; Kreggenfeld, N.; Kreimeier, D.; Kuhlenkötter, B. Learning Factory Modules for Smart Factories in Industrie 4.0. Procedia CIRP 2016, 54, 113-118. [CrossRef]

96. Longo, F.; Nicoletti, L.; Padovano, A. Smart operators in industry 4.0: A human-centered approach to enhance operators capabilities and competencies within the new smart factory context. Comput. Ind. Eng. 2017, 113, 144-159. [CrossRef]

97. Louw, L.; Deacon, Q. Teaching Industrie 4.0 technologies in a learning factory through problem-based learning: Case study of a semi-automated robotic cell design. Procedia Manuf. 2020, 45, 265-270. [CrossRef]

98. Chaim, O.; Muschard, B.; Cazarini, E.; Rozenfeld, H. Insertion of sustainability performance indicators in an industry 4.0 virtual learning environment. Procedia Manuf. 2018, 21, 446-453. [CrossRef]

99. Wittenberg, C. Human-CPS Interaction-Requirements and human-machine interaction methods for the Industry 4.0. IFAC-Pap. 2016, 49, 420-425. [CrossRef]

100. Sony, M.; Naik, S. Industry 4.0 integration with socio-technical systems theory: A systematic review and proposed theoretical model. Technol. Soc. 2020, 61, 101248. [CrossRef]

101. Baena, F.; Guarin, A.; Mora, J.; Sauza, J.; Retat, S. Learning Factory: The Path to Industry 4.0. Procedia Manuf. 2017, 9, 73-80. [CrossRef]

102. Karre, H.; Hammer, M.; Kleindienst, M.; Ramsauer, C. Transition towards an Industry 4.0 State of the LeanLab at Graz University of Technology. Procedia Manuf. 2017, 9, 206-213. [CrossRef]

103. Büth, L.; Blume, S.; Posselt, G.; Herrmann, C. Training concept for and with digitalization in learning factories: An energy efficiency training case. Procedia Manuf. 2018, 23, 171-176. [CrossRef]

104. Tosello, E.; Castaman, N.; Menegatti, E. Using robotics to train students for Industry 4.0. IFAC-Pap. 2019, 52, 153-158. [CrossRef]

105. Sallati, C.; de Andrade Bertazzia, J.; Schützer, K. Professional skills in the Product Development Process: The contribution of learning environments to professional skills in the Industry 4.0 scenario. Procedia CIRP 2019, 84, 203-208. [CrossRef]

106. Liagkou, V.; Salmas, D.; Stylios, C. Realizing Virtual Reality Learning Environment for Industry 4.0. Procedia CIRP 2019, 79, 712-717. [CrossRef]

107. Hennig, M.; Reisinger, G.; Trautner, T.; Hold, P.; Gerhard, D.; Mazak, A. TU Wien Pilot Factory Industry 4.0. Procedia Manuf. 2019, 31, 200-205. [CrossRef]

108. Dombrowski, U.; Wullbrandt, J.; Fochler, S. Center of Excellence for Lean Enterprise 4.0. Procedia Manuf. 2019, 31, 66-71. [CrossRef]

109. Oestreich, H.; Töniges, T.; Wojtynek, M.; Wrede, S. Interactive Learning of Assembly Processes using Digital Assistance. Procedia Manuf. 2019, 31, 14-19. [CrossRef]

110. Scholz, J.-A.; Sieckmann, F.; Kohl, H. Implementation with agile project management approaches: Case Study of an Industrie 4.0 Learning Factory in China. Procedia Manuf. 2020, 45, 234-239. [CrossRef]

111. Wermann, J.; Colombo, A.W.; Pechmann, A.; Zarte, M. Using an interdisciplinary demonstration platform for teaching Industry 4.0. Procedia Manuf. 2019, 31, 302-308. [CrossRef]

112. Landherr, M.; Schneider, U.; Bauernhansl, T. The Application Center Industrie 4.0-Industry-driven Manufacturing, Research and Development. Procedia CIRP 2016, 57, 26-31. [CrossRef]

113. Santos, K.; Loures, E.; Piechnicki, F.; Canciglieri, O. Opportunities Assessment of Product Development Process in Industry 4.0. Procedia Manuf. 2017, 11, 1358-1365. [CrossRef]

114. Zaimovic, T. Setting speed-limit on Industry 4.0-an outlook of power-mix and grid capacity challenge. Procedia Comput. Sci. 2019, 158, 107-115. [CrossRef]

115. Lu, Y. Industry 4.0: A survey on technologies, applications and open research issues. J. Ind. Inf. Integr. 2017, 6, 1-10. [CrossRef]

116. Inkermann, D.; Schneider, D.; Martin, N.L.; Lembeck, H.; Zhang, J.; Thiede, S. A framework to classify Industry 4.0 technologies across production and product development. Procedia CIRP 2019, 84, 973-978. [CrossRef]

117. Frank, A.G.; Dalenogare, L.S.; Ayala, N.F. Industry 4.0 technologies: Implementation patterns in manufacturing companies. Int. J. Prod. Econ. 2019, 210, 15-26. [CrossRef]

118. Pacchini, A.P.T.; Lucato, W.C.; Facchini, F.; Mummolo, G. The degree of readiness for the implementation of Industry 4.0. Comput. Ind. 2019, 113, 103125. [CrossRef]

119. García, S.G.; García, M.G. Industry 4.0 implications in production and maintenance management: An overview. Procedia Manuf. 2019, 41, 415-422. 
120. Sahal, R.; Breslin, J.G.; Ali, M.I. Big data and stream processing platforms for Industry 4.0 requirements mapping for a predictive maintenance use case. J. Manuf. Syst. 2020, 54, 138-151. [CrossRef]

121. Oberc, H.; Prinz, C.; Glogowski, P.; Lemmerz, K.; Kuhlenkötter, B. Human Robot Interaction-learning how to integrate collaborative robots into manual assembly lines. Procedia Manuf. 2019, 31, 26-31. [CrossRef]

122. Dilberoglu, U.M.; Gharehpapagh, B.; Yaman, U.; Dolen, M. The Role of Additive Manufacturing in the Era of Industry 4.0. Procedia Manuf. 2017, 11, 545-554. [CrossRef]

123. Merayo, D.; Rodríguez-Prieto, A.; Camacho, A.M. Comparative analysis of artificial intelligence techniques for material selection applied to manufacturing in Industry 4.0. Procedia Manuf. 2019, 41, 42-49. [CrossRef]

124. Muñoz-Saavedra, L.; Miró-Amarante, L.; Domínguez-Morales, M. Augmented and Virtual Reality Evolution and Future Tendency. Appl. Sci. 2020, 10, 332. [CrossRef]

125. Masoni, R.; Ferrise, F.; Bordegoni, M.; Gattullo, M.; Uva, A.E.; Fiorentino, M.; Carrabba, E.; Di Donato, M. Supporting Remote Maintenance in Industry 4.0 through Augmented Reality. Procedia Manuf. 2017, 11, 1296-1302. [CrossRef]

126. Gattullo, M.; Scurati, G.W.; Fiorentino, M.; Uva, A.E.; Ferrise, F.; Bordegoni, M. Towards augmented reality manuals for industry 4.0: A methodology. Robot. Comput. Integr. Manuf. 2019, 56, 276-286. [CrossRef]

127. Ceruti, A.; Marzocca, P.; Liverani, A.; Bil, C. Maintenance in aeronautics in an Industry 4.0 context: The role of Augmented Reality and Additive Manufacturing. J. Comput. Des. Eng. 2019, 6, 516-526. [CrossRef]

128. Boyack, K.W.; Klavans, R.; Börner, K. Mapping the backbone of science. Scientometrics 2005, 64, 351-374. [CrossRef]

129. Jacomy, M.; Venturini, T.; Heymann, S.; Bastian, M. ForceAtlas2, a Continuous Graph Layout Algorithm for Handy Network Visualization Designed for the Gephi Software. PLoS ONE 2014, 9, e98679. [CrossRef] [PubMed]

130. Li, D.; Landström, A.; Fast-Berglund, Å.; Almström, P. Human-Centred Dissemination of Data, Information and Knowledge in Industry 4.0. Procedia CIRP 2019, 84, 380-386. [CrossRef]

131. Yildiz, T. Examining the Concept of Industry 4.0 Studies Using Text Mining and Scientific Mapping Method. Procedia Comput. Sci. 2019, 158, 498-507. [CrossRef]

132. Mariani, M.; Borghi, M. Industry 4.0: A bibliometric review of its managerial intellectual structure and potential evolution in the service industries. Technol. Forecast. Soc. Chang. 2019, 149, 119752. [CrossRef]

133. Muhuri, P.K.; Shukla, A.K.; Abraham, A. Industry 4.0: A bibliometric analysis and detailed overview. Eng. Appl. Artif. Intell. 2019, 78, 218-235. [CrossRef]

134. Pellegrini, T.; Blumauer, A. Semantic Web: Wege zur Vernetzten Wissensgesellschaft; Springer: Berlin/Heidelberg, Germany, 2006; Available online: https://www.springer.com/de/book/9783540293248 (accessed on 30 November 2020).

135. Tantik, E.; Anderl, R. Industrie 4.0: Using Cyber-physical Systems for Value-stream Based Production Evaluation. Procedia CIRP 2016, 57, 207-212. [CrossRef]

136. Ezugwu, A.E.; Shukla, A.K.; Agbaje, M.B.; Oyelade, O.N.; José-Garcia, A.; Agushaka, J.O. Automatic clustering algorithms: A systematic review and bibliometric analysis of relevant literature. Neural Comput. Appl. 2020. [CrossRef]

137. Borges, A.F.S.; Laurindo, F.J.B.; Spínola, M.M.; Goncalves, R.F.; Mattos, C.A. The strategic use of artificial intelligence in the digital era: Systematic literature review and future research directions. Int. J. Inf. Manag. 2021, 57, 102225. [CrossRef] 